\title{
New information on the biology of Antarctic deep-water sponges derived from underwater photography
}

\author{
Dagmar Barthel $^{1}$, Julian Gutt ${ }^{2}$, Ole S. Tendal ${ }^{3}$ \\ 1 Dept of Marine Botany, Institut für Meereskunde, Düsternbrooker Weg 20, D-2300 Kiel, Germany \\ ${ }^{2}$ Alíred-Wegener-Institut für Polar- und Meeresforschung, Columbusstr., D-2850 Bremerhaven, Germany \\ ${ }^{3}$ Zoologisk Museum, Universitetsparken 15, DK-2100 Copenhagen O, Denmark
}

\begin{abstract}
Aspects of the biology of sponges from deeper parts of the Antarctic Weddell Sea, documented by underwater photography, are described and compared to material from bottom trawling. The photographs provide new, important information on the biology and ecology of Antarctic sponges, such as positioning on the sea bottom, live body form and dimensions, as well as on the degree of body surface fouling Such information is not obtainable from trawled material.
\end{abstract}

During Leg III of the European Polarstern Study (EPOS), about 1500 pictures of the Weddell Sea bottom along transects at Halley Bay, Vestkapp and Kapp Norvegia were taken in depths between 100 and $1200 \mathrm{~m}$ at 24 stations (Arntz et al. 1990). The main aim of this effort was to elucidate small- and large-scale variations in species composition and community structure of Antarctic benthos and to provide additional data for biomass estimates of the larger benthic organisms in areas that are out of a diver's reach and can only be sampled by bottom trawling, box cores, etc.

One of the main target groups were sponges (Arntz et al. 1990), which greatly contribute to the 'multistoried' (Knox 1970) structure of Antarctic benthic communities, characterized by high diversity, patchy distributions, little infauna, as well as a high degree of eurybathy and slow growth of most of its members (see reviews by Picken 1984 and White 1984). The large hexactinellids which are dominant in many Antarctic habitats (e.g. Beliaev \& Ushakov 1957, cited in Gallardo 1987, Dayton et al. 1970, Koltun 1970) including the eastern Weddell Sea shelf (Voss 1988) have repeatedly been documented in bottom photographs (e.g. Bullivant 1961, Dearborn 1977, Dayton 1979) while demosponges, which contribute far more species, have received less attention.

A first step towards a numerical analysis of our photographs was the task of recognizing species on the basis of material taken from trawls during the same cruise, mostly from the same stations. The pictures provided valuable information on the biology of Antarctic sponges and helped to answer some of the questions posed by work on trawled material.

We here present a few 'case studies' in order to demonstrate the potential of photographic documentation in understanding the biology and ecology of deepwater sponges.

Material and methods. Square photographs (Kodak Ektachrome 64) were taken with a $70 \mathrm{~mm}$ underwater camera (Hasselblad 500 EL/M with Metz mecablitz 40 CT4 flash) (Gutt 1988). The shutter was released at a constant distance from the sea floor by means of a trigger weight. Thus, the size of the photographed area $\left(0.56 \mathrm{~m}^{2}\right)$ and the size of the photographed objects could be calculated. Pictures were taken 'blind' without control over the exact sampling place. For details of methods see Hersey (1967) and Heezen \& Hollister (1971). Specimens were collected with Agassiz and bottom trawls towed for ca 1 h at a speed of 1 knot.

'Case study' 1. Cinachyra antarctica (Carter, 1872). Common occurrence in many Antarctic areas at depths from 18 to $780 \mathrm{~m}$ (Koltun 1966, present study). Diagnosis (by Koltun):

'Body more or less rounded, maximum diameter $6 \mathrm{~cm}$. Surface with conules bearing long bundles of spicules at their tips. Conules situated obliquely and disposed in a spiral pattern. The bundles of spines are especially long in the inferior part of the body where they form a radicular tangle. Among the conules there are round or oval areas (up to $0.5 \mathrm{~cm}$ diameter) which are covered with pores. There is also an oscular surface which has a maximum diameter of $3.25 \mathrm{~mm}$. Color [Koltun refers to alcohol preserved material]: gray, grayish brown or light brown. Skeleton radial-spiral. 
Except for the colour, which is mostly more greenish, Koltun's diagnosis aptly describes the appearance of freshly caught Cinachyra antarctica (Fig. 1a), and it is difficult to imagine how this dense spiral entity functions in its natural environment. Fig. $1 \mathrm{~b}$ shows live $C$. antarctica in their habitat. It becomes clear that the typical spiral body pattern is due to a contraction artefact and that the living sponge is not dense but very cavernous, with large pores and an oscular area much larger than can be reckoned from caught specimens. The fact that this species is much more distended in its natural state and that the spicule tufts extend perpendicular to the surface results in much larger space requirements and has a bearing on calculations of average bottom surface coverage. The same holds true for determinations of the filtering surface of $C$. antarctica, which obviously lead to underestimations if based on trawled specimens.

'Case study' 2. Monosyringa longispina (Lendenfeld 1907). This species is common in many Antarctic areas in depths from 125 to $1340 \mathrm{~m}$ (Koltun 1966). Fig. 2a shows the typical appearance of a trawled specimen. While most of the sponge body is clean, the surface between the apical papillae is covered with sediment, shell debris, etc. often fixed to the sponge. Fig. $2 b$ indicates that this material did not accumulate there during trawling, but that it represents the last remnants of the sediment normally covering $M$. longispina, whose body is totally embedded in the substrate with only the papillae protruding. Traditionally, these papillae are referred to as oscular, i.e. exhalant tubes (e.g. Koltun 1967). Ecological implications are that to live buried in the sediment provides both protection from potential predators and an advantage in substrate competition, when the large body of $M$. longispina is beneath the surface and the only space required is that for the protrusion of the comparatively thin papillae. Thus, growth of the sponge can take place even partly underneath other epibenthic organisms. This can be of importance in Weddell Sea habitats inhabited by dense benthic associations. Also, considering the position of the sponge in the sediment, the so-called oscular papillae are probably partly ex- and partly inhalant, which would make the structure comparable to that of the related species Disyringa dissimilis (Ridley 1884) which has one inhalant and one exhalant papilla (Fry \& Fry 1978).

Fig. 1. Cinachyra antarctica. (a) Freshly dredged specimen, extremely contracted, with spicule bundles forming a spiral pattern over the whole body surface; in- and exhalant openings are barely visible; Stn 230, Halley Bay, $270 \mathrm{~m}$ water depth. (b) Live specimen in natural habitat, seen from above; diameter $9 \mathrm{~cm}$; body distended with spicule bundles extending perpendicular from the body surface; the large apical pores mark the oscular (exhalant) area; Stn 276, off Kapp Norvegia, $118 \mathrm{~m}$ water depth
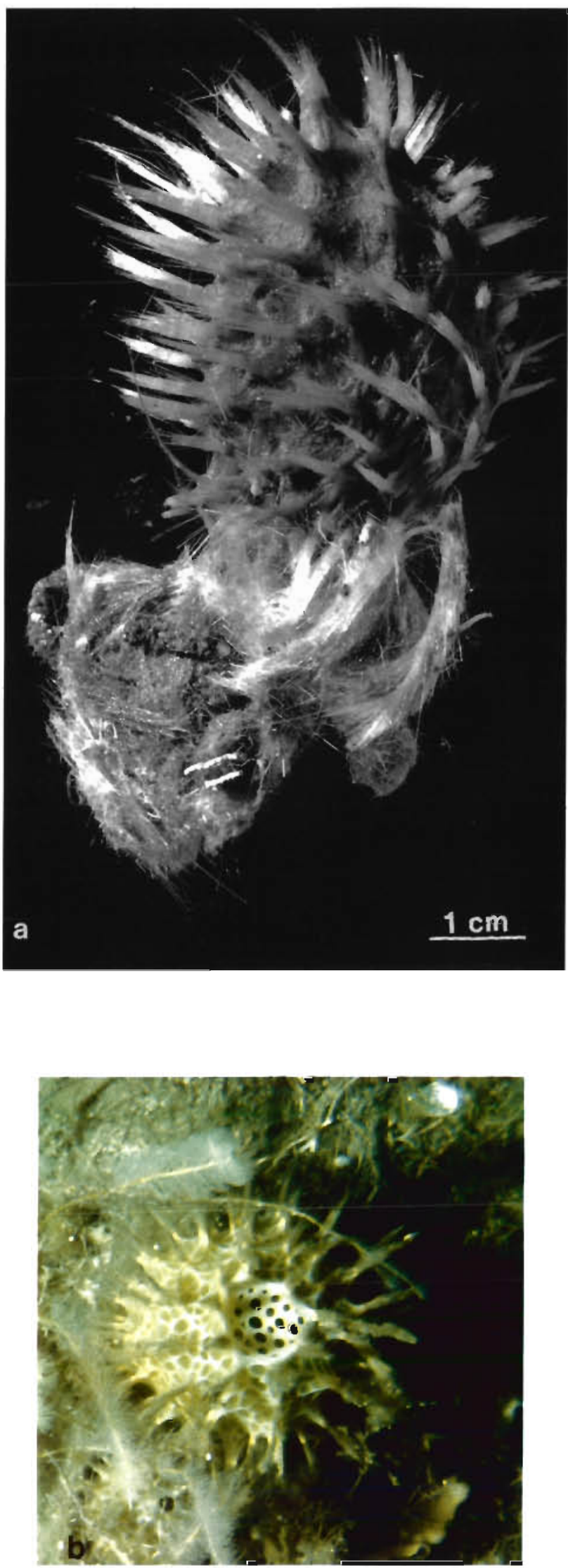
Fig. 2. Monosyringa longispina. (a) Freshly dredged specimen, side view; water-conducting papillae tom; sediment and debris remain only between papillae; Stn 274, off Kapp Norvegia, 300 $m$ water depth. (b) Live specimen in natural habitat; the sponge is completely buried in the sediment with only the papillae extending above the substrate; note brittle stars attached to, and between, the papillae; diameter of sponge ca 20 $\mathrm{cm}$. Stn 304, off Kapp Norvegia, $100 \mathrm{~m}$ water depth
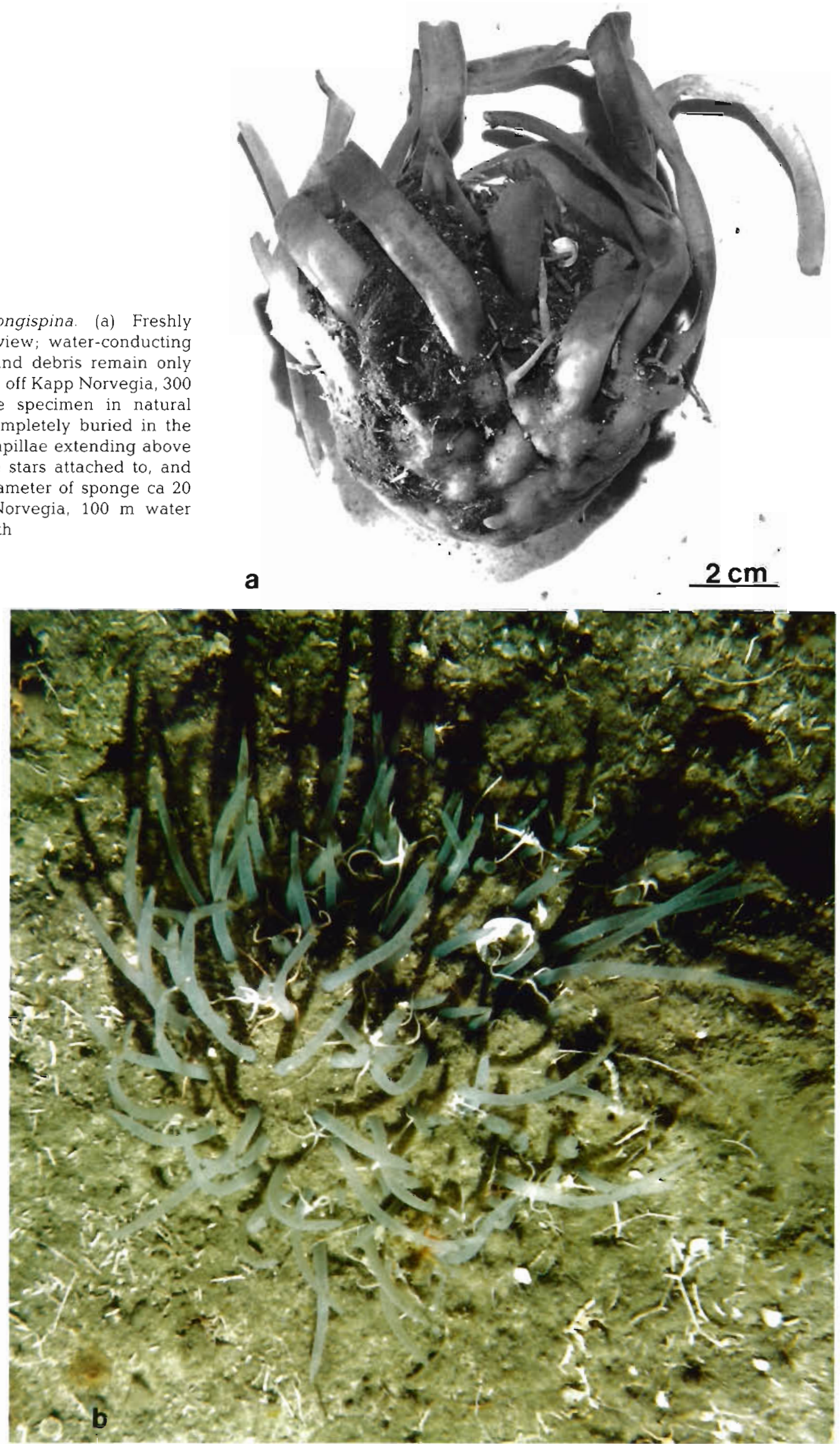
'Case study' 3. Associations of sponges and other benthic organisms.

As stated by Dayton et al. (1970) and Dearborn (1977), sponges in the Antarctic provide an important substratum for numerous epibenthic sessile or motile organisms; they are often the only elevated structures present. However, it is impossible to describe associations in greater depths from trawl catches: organisms found, for example, in the large oscula of hexactinellids might not have been there under in situ conditions, and others, originally living on or in sponges, may have been torn off or washed out due to trawling. Fig. 3 shows crinoids perched on large hexactinellids; here they may be able to reach a water layer with higher current velocities and advantages in food requisition as compared to the conditions close to the bottom surface. Monosyringa longispina, for example, provides a special environment for brittle stars which are concentrated on and between its papillae (Fig. 2b)

Conclusions. Our case studies exemplify information obtainable by in situ photography of deep-water Antarctic sponges. For the first time in research on deep Antarctic sponges, we are now able to use live observations as control and background for interpretations derived from newly caught and, as is mostly the case, long-preserved material. Dayton (1979) and Dayton et al. (1974) used photographs taken by divers in determining growth rates and size-frequency distributions of dominant sponge species at McMurdo Sound but relative to the total benthic area in the Antarctic the regions accessible for divers are small. It is in deeper waters that underwater photography is most useful, providing information not only on species com position and density, but also on qualitative biological and ecological aspects otherwise unavailable. Direct photographic analysis of Antarctic benthos is essential for our understanding of ecological interactions in these benthic communities, as well as for comprehending the biology of single species. Additionally, information may become available for species identification.

Acknowledgements. The information presented was obtained during the European 'Polarstern' Study (EPOS) sponsored by the European Science Foundation and the Alfred Wegener Institute for Polar and Marine Research. During picture evaluation we enjoyed the hospitality of the Havbiologisk Feltlaboratorium, Frederikshavn (University of Copenhagen, Denmark). We thank G. Brovad for photography of preserved specimens. The study was in part supported by the Deutsche Forschungsgemeinschaft, grant BA 913/2 to D. Barthel. This is publication no. 262 of the Alfred-Wegener-Institute.

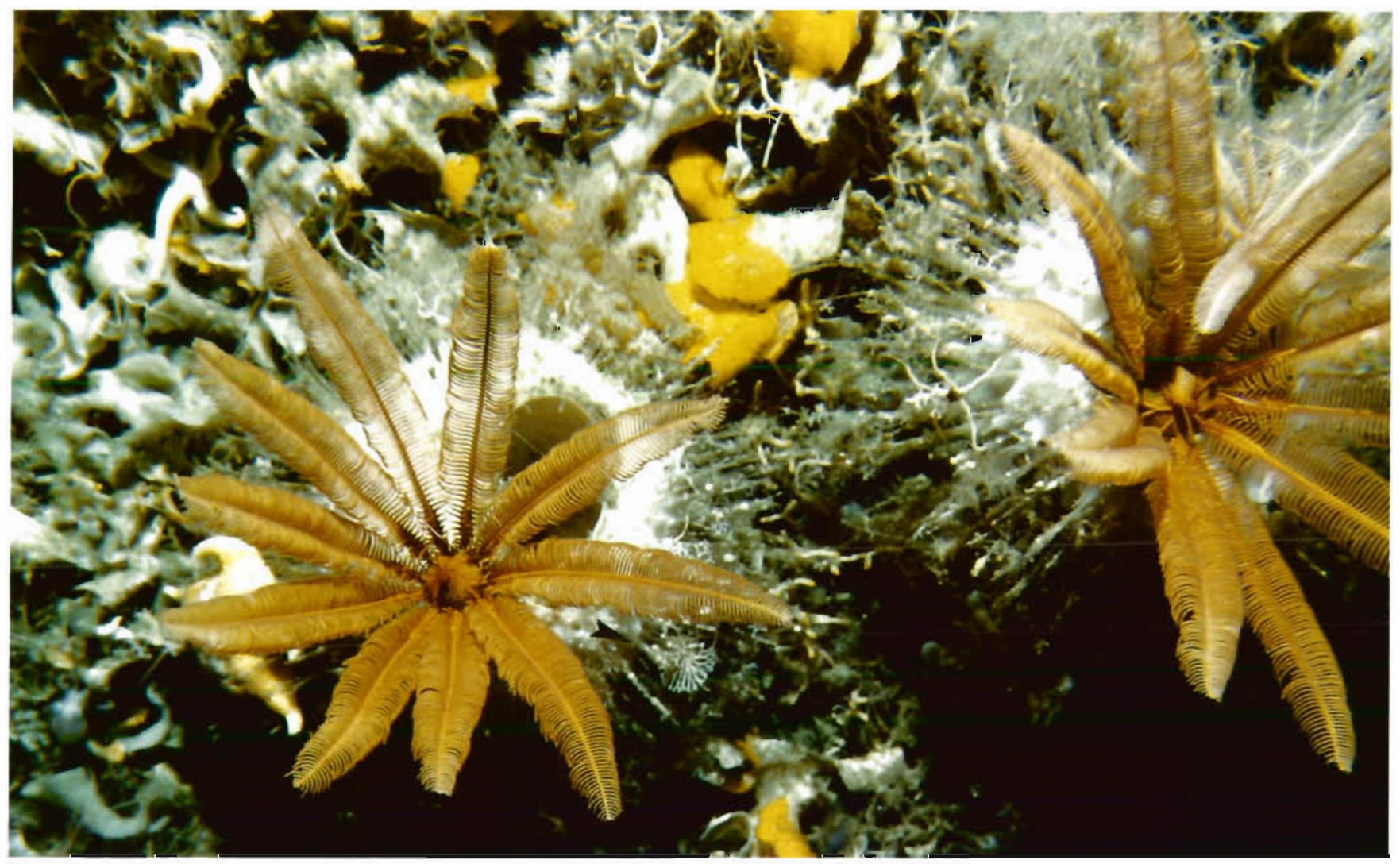

Fig. 3. Crinoids perched on top of large hexactinellids. Superficial spicules serve as substrate for numerous smaller organisms such as bryozoans or foraminiferans; diameter of hexactinellids (excluding spicules) ca $13 \mathrm{~cm}$. Stn 275 , off Kapp Norvegia. $301 \mathrm{~m}$ water depth 


\section{LITERATURE CITED}

Arntz, W., Ernst, W., Hempel, 1. (1990). The expedition Antarctis VII/4 (EPOS leg 3) and VII/5 of RV 'Polarstern' in 1989. Ber Polarforsch. (Reports on Polar Research) 68: 153-157

Bullivant, J. S. (1961). Photographs of Antarctic bottom fauna. Polar Rec. 68: 505-508

Dayton, P. K. (1979). Observations on growth, dispersal and population dynamics of some sponges in McMurdo Sound, Antarctica. In: Levi, C., Boury-Esnault, N. (eds.) Bıologie des spongiaires. Colloques int. Cent. natn. Rech. Scient. 291: $271-282$

Dayton, P. K., Robilliard, G. A., Paine, R. T (1970). Benthic faunal zonation as a result of anchor ice at MCMurdo Sound, Antarctica. In: Holdgate, M. W. (ed.) Antarctic ecology, Vol. 1. Academic Press, London, p. 244-258

Dayton, P. K., Robilliard, G. A., Paine, R. T., Dayton, L. B. (1974). Biological accomodation in the benthic community of McMurdo Sound, Antarctica. Ecol. Monogr. 44 (1): 105-128

Dearborn, J. H. (1977). Foods and feeding characteristics of Antarctic asteroids and ophiuroids. In: Llano, G. A. (ed.) Adaptations within Antarctic ecosystems. Proc of the 3rd SCAR Symposium on Antarctic Biology. Smithsonian Institute, Washington, D.C., p. 293-326

Fry, W. G., Fry, P. D. (1978). Aspects of the functional anatomy and ecological physiology of Disyringa and some other infaunal tetractinomorph sponges. In: Levi, C., BouryEsnault, N. (eds.) Biologie des spongiaires. Colloques int. Cent. natn. Rech. Scient. 291 335-341

This note was submitted to the editor
Gallardo, V A. (1987). The sublittoral macrofaunal benthos of the Antarctic shelf. Environ. int. 13: 71-81

Gutt, J. (1988). Zur Verbreitung und Ökologie der Seegurken (Holothuroidea, Echinodermata) im Weddellmeer (Antarktis). Ber. Polarforsch. (Reports on Polar Research) 41,87 pp.

Heezen, B. C., Hollister, C. D. (1971). Face of the deep. Oxford University Press, London

Hersey, J. B. (1967). Deep sea photography. The Johns Hopkins oceanographic studies No. 3. The Johns Hopkins Press, Baltimore

Knox B. A. (1970). Antarctic marine ecosystems. In: Holdcate M. W. (ed.) Antaractic ecology, Vol. 1. Academic Press London, p. 69-96

Koltun, V M. (1966). Sponges of the Antarctic. I. Tetraxonida and Cornacuspongia. In: Andriyashev, A. F, Ushakov, P. $V$ (eds.) Biological reports of the Soviet Antarctic Expedition (1955-1958), Vol. 2. Transl. Israel Prog. f. Sci. Transl. Oldbourne Press, London, $459 \mathrm{p}$.

Koltun, V M. (1970). Sponges of the Arctic and the Antarctic a faunistic review. Symp. zool. Soc. London 25: 285-297

Picken, G. B. (1984). Marine habitats - benthos. In: Bonner, W N., Walton, D. W. H. (eds.) Key environments: Antarctica. Pergamon Press, Oxford, p. 154-172

Voss, J. (1988). Zoogeographie und Gemeinschaftsanalyse des Makrozoobenthos des Weddellmeeres (Antarktis). Ber. z. Polarf. 45: 1-144

White, M. G. (1984). Marine benthos. In: Laws, R. M. (ed.) Antarctic ecology, Vol. 2. Academic Press, London, p. $421-461$

Manuscript first received: September 7, 1990

Revised version accepted. November 9, 1990 